Kristina Malmio

\title{
Fagerholm goes Oprah: Minor literature, global market, and gender in literary exchange
}

\begin{abstract}
In this article, I study the journey of the Finland-Swedish author Monika Fagerholm's (b. 1961) novel The American Girl to the pages of $O$, The Oprah Magazine. This event, here called "Fagerholm goes Oprah" offers an illustrative example of the global movements of literature today, and of the ongoing negotiation of relations between local and global, the Nordic countries and the USA, minor literature and the global market. The article describes the different phases of the transmission of this novel, studies the means by which a novel from a minor body of literature transgresses its geo-linguistic position and, in this specific case, demonstrates the role of gender. In this way, the novel not only creates fictive, transnational spaces for its female characters and readers, but it also enters and contributes to a network of female agents in widely different geographical and cultural contexts. The event "Fagerholm goes Oprah" is a sign of the ongoing globalization of the literary field, but its reception also reveals the presence of an opposing tendency: the continuing significance of localization in literary exchange. All in all, the novel and its reception illustrate the many strategies used to create a connection between two different cultures, and also display the importance of various cultural currents in the transmission of the novel, such as feminism and Nordic Noir.
\end{abstract}


Key words: Monika Fagerholm, literary exchange, minor literature, world literature, female networks, translation, reception, gender, Oprah Winfrey

In April 2010, an extraordinary event took place in the history of Finland-Swedish literature: The American Girl, a translation of Monika Fagerholm's novel Den amerikanska flickan, was reviewed in $O$, The Oprah Magazine. The combination of a minority-language author from a small Nordic country, an aesthetically experimental story, and Oprah Winfrey's Book Club, the "most powerful market force in American publishing" (Pereira, 2009, p. 200), is both unusual and unexpected, and raises many questions. How did the novel make its way to a media celebrity's book club and how did it prepare its entrance? Who and what are the actors and phases of transmission and how was it received? And finally, what is the relevance of gender in this specific case of transnational literary exchange?

The circulation of literature outside its context of origin has been studied under various headings, including: world literature, postcolonialism, transnationalism, cultural transfer, literary exchange, transmission and translation, just to mention a few of the latest developments in research. Although an old phenomenon, during the last few decades it has achieved an intensified actuality through the "ongoing acceleration of economic and cultural globalization" (Damrosch, 2009b, p. 106). The transmission of literary texts from the culture that produced them to new contexts of reception is a complex process, and the uneven conditions and power relations of major cultures and minor literatures in translation, transmission and reception have been widely acknowledged (Bermann, 2012, p. 175; Venuti, 2012; Damrosch, 2009a, p. 194). In addition, the many problems related to gender in crosscultural communication have been pointed out (Castillo, 2012, p. 393). Knowing all this, the 
task of current research is to explore more fully what "world" literature - as well as "translation" and "transmission" - mean from different geo-linguistic standpoints, as argued by Sandra Bermann (2012, p. 176).

This is exactly where this article comes in. In it, I scrutinize a case of transnational literary exchange, the journey of a "highbrow" female and feminist Nordic author into a very specific American context, the book club created by the media personality and phenomenon Oprah Winfrey. Firstly, I study the ways in which author Monika Fagerholm reaches out to the recipient culture in her novel, then I take a look at the transmission of the novel, before going on to analyse the reception of The American Girl in $O$, The Oprah Magazine. I also discuss the role of gender during the different phases of the novel's journey to the USA. Altogether, I hope this article will result in a deeper understanding, not only of the geolinguistic conditions of minor literature in literary transmission, but also of the strategies used by the author to create a connection between two cultures within the contemporary global market of literature, and of the localizing practices that take place in reception.

Translations are of course the first and foremost means for transporting a novel from one culture to another, but it is not the translation as such that is the object of my interest. I approach this case of literary exchange using the concepts of "world literature" and "minor literature". According to Petra Broomans and Ester Jiresch (2011, pp. 10-13), the process of cultural transfer includes the following phases: 1). discovery, 2). quarantine, 3). translation, 4). publication of translation, 5). reception of the published translation, and 6). postpublication reception. ${ }^{1}$ Although the list of phases of cultural transfer in Broomans and Jiresch's account is quite detailed, I find it insufficient on some points. For one thing, it leaves out a possible level of importance; namely, earlier translations of a writer's works. Moreover, it pays no attention to the characteristics of the novel to be culturally transferred. This is where David Damrosch's views on world literature enter. According to him, "a work of world 
literature has an exceptional ability to transcend the boundaries of the culture that produces it - reach out beyond its own time and place" (Damrosch, 2009a, p. 2). He suggests that literary works employ a variety of strategies by which they may enter the realm of world literature, overcome cultural distance and reach audiences in a globalizing world, some of which I will use in my analysis of The American Girl. The material considered in this article consists of the novel The American Girl and the review of it published in Oprah Winfrey's book club, ${ }^{2}$ and my method is that of textual analysis. As well as the strategies used by the novelist to enable her novel to travel from one culture to another, the focus is on the reception of the translation in $O$, The Oprah Magazine. ${ }^{3}$

Being an example of minor literature, Den amerikanska flickan enters a global literary market when it is introduced in Oprah Winfrey's book club. What I offer here, then, is a case study of literary exchange. I do not think that there is a ready-made, one-way route for a novel to become global; the journeys of novels into huge markets are many and depend on various coincidences and other factors. As Ann Steiner states, "internationally spread texts are characterized by their great variety" $(2012$, p. 316). However, I argue that a closer scrutiny of "Fagerholm goes Oprah" exposes the most important reasons for this specific case of literary exchange, and demonstrates the central importance of gender in it. The uniqueness of Fagerholm's novels has been emphasized, and is described aptly by Lena Kvist (2005) in her review of Den amerikanska flickan: "There are Finnish authors, Swedish authors, FinlandSwedish authors. And then there is Monika Fagerholm. It is as though she came from a land of her own" (my transl.). Reformulating Kvist, I claim that the "land of her own" which both Fagerholm and Winfrey occupy and share, is a transnational, female and feminist space.

What were the phases of transmission and the factors that played a part and enabled The American Girl to enter Oprah Winfrey's book club? And how was the novel received? Before answering these questions, I will give a short introduction to Fagerholm's oeuvre and 
literary career, the conditions of Finland-Swedish literature as a minor literature and the phases of transmission that took place before The American Girl entered Oprah Winfrey's website.

\section{A feminist author of minor literature with girlhood as her major topic}

Monika Fagerholm (b. 1961) is known in the Nordic countries and especially in Finland and Sweden for her experimental style, and for her wild and visionary depictions of girlhood. She is a feminist writer, who in many interviews has openly declared that her authorship aims to give voice to those groups in society that have been sidestepped and marginalized, such as young children, teenage girls, and housewives (see e.g., Kurikka, 2009, p. 38). Fagerholm is probably the most important contemporary Finland-Swedish author and has many literary followers among young female authors in Sweden and Finland.

After a couple of collections of short stories published in the late 1980s and early 1990s, Fagerholm's first novel, Underbara kvinnor vid vatten [Wonderful Women by the Sea] $(1994)^{4}$, a pastiche of the lives and fates of two families during a couple of sunny summers in the 1960s, became an immediate success. It was translated into several languages and was even filmed. In 1998, Fagerholm published Diva, a novel about a 13-year-old schoolgirl in 600 pages, told exclusively from her perspective and in her language. Diva was also translated into a couple of languages, but not into English. In the reviews of the novel, Diva, the eponymous protagonist, was apprehended as a feminist counterpart to the teenage rebel Holden Caulfield in J. D. Salinger's cult novel Catcher in the Rye (1951). This highly experimental and postmodern monologue of a schoolgirl in a suburb of Helsinki during the early 1970s was followed by Fagerholm's major breakthrough, Den amerikanska flickan, 
which, among many other prizes, was awarded the August Prize in Sweden for the best novel written in Swedish in 2005 (Ingström, 2014; Malmio \& Österlund, 2016).

Den amerikanska flickan was published in Finland in 2004 and in Sweden in $2005 .{ }^{5}$ It is a complicated story about a girl from the USA, Eddie de Wire, who dies in Finland, but the real protagonists of the novel are Sandra and Doris, two young and lonely girls who become friends and create a world of their own by fantasizing, narrating, playing and mimicking the death of the American girl. They share a problematic family background; Doris's mother has mistreated her, while Sandra's mother has abandoned her husband and daughter for a lover. The girls become the most important people in each other's lives, but later on they drift apart, with tragic consequences.

The novel is written in a style characterized by repetition, short scenes, constantly varying perspectives, and a fragmented and at times awkward use of language. It takes place simultaneously on several different levels of narration, time and place. Hence, the story refuses to be summarized neatly; narrated in a postmodern, self-reflexive manner, it offers several possible endings and different solutions to its central enigma, the death of Eddie. Due to the great emphasis on emotions and the many dramatic deaths that take place in the story, literary scholar Anna Helle has characterized The American Girl as a postmodern melodrama (Helle, 2016). On the internet pages of Other Press, Fagerholm's publisher in New York, the novel is described as a crime mystery, a Gothic saga, a chronicle of the late 1960s and early 1970s, a social study and a story of the psyche of young girls and their sexual awakening (http://www.otherpress.com/books/the-american-girl/). Features typical of reader-friendly realism - suspense, interesting characters and convincing depictions of a milieu - are countered in Fagerholm's prose by a daring renewal of the narrative conventions of prose (Ingström, 2014). The reviewers have compared Fagerholm's style to authors like William 
Faulkner, Joyce Carol Oates, Toni Morrison and Peter Høeg, and literary critics and scholars emphasize her ability to unite entertainment with experimentation.

"Minor literature", a term coined by Gilles Deleuze and Félix Guattari to describe Franz Kafka's use of the German language in Prague, has been employed by literary scholars to describe the quality and strategies of Finland-Swedish literature during the early twentieth century (Zilliacus, 2000, pp. 16-18; Tidigs, 2014). A characteristic of minor literature is that it is written in a dominant language that is constantly deterritorializing itself. Rather than a minority literature, it is a "minorization" of the major language by making it strange and unknown (Kurikka, 2016, pp. 44-45). The term was later adopted by David Damrosch to broaden the scope of "world literature". In order to incorporate more works from small literatures into world literature, he uses "minor literature" in three senses; to include, firstly, minority-group writing (e.g., Gaelic, Yiddish) "within major powers"; 6 secondly, the literatures of smaller countries (e.g., Guatemala, Hungary); and thirdly, works from languages and regions rarely represented in North American syllabi (Damrosch, 2009b, p. 194). This wide - and partially USA-biased - interpretation of the term covers several geo-linguistic aspects of interest here.

Despite the fact that Swedish is the second official language of Finland, and thus one of Finland's two national languages, it is a minority language spoken today by only about $5 \%$ of the population (approximately 300000 persons). In the past, Swedish was the language of higher education, administration and culture in Finland. However, during the Finnish nationbuilding process of the nineteenth century, Finnish gradually replaced Swedish as the "official" language number one. At the beginning of the twentieth century, authors who wrote in Swedish in Finland became finally fully aware of their new status and identity as authors of a minority literature. This had many consequences for both them and their works, as well as for the literary field of Finland-Swedish literature. 
Den amerikanska flickan is an example of minor literature, then, in all three senses in which Damrosch uses the term. Not only is it written by an author who belongs to the Swedish minority in Finland and uses a deterritorialized Swedish, it also belongs to minor literature in a global context as it comes from a small Nordic country and enters the powers of a global literary market. Moreover, it is a text from a region that seldom enters the US curriculum, except perhaps in courses on Scandinavian literature.

Wolfgang Behschnitt and Magnus Nilsson (2013), who have studied the linguistic, socio-political, economic and institutional conditions of the production, distribution and reception of literature in small language areas, argue that literary circulation in Sweden, Denmark, and the Netherlands still takes place within the national framework, and faces many difficulties when trying to reach international readers. ${ }^{7}$ Surely the obstacles are even more profound for Finland-Swedish literature. An author of minor literature like Fagerholm already faces difficulties when trying to reach a national, in this case Finnish, audience. Nor is it easy for a Finland-Swedish author to get publicity or readers in Sweden, and it is even more difficult for a minor literature to enter the literary market of the USA. According to Julie K. Allen, of the 15000 books published in the USA each year, only $2 \%$ are translations (Allen, 2017). Huge nations with dominant languages and vast literary markets are, as literary sociologists have noticed, much less inclined to translate literature than small nations with minority languages.

\section{The American Girl as world literature}

In its widest sense, the term "world literature" covers all the texts in the world, and texts can enter the realm of world literature in different ways, Damrosch argues. ${ }^{8}$ They can circulate out into the world by finding readers in distant times, places and languages, but they might 
also bring "the world directly into the text itself"; an author can make use of foreign literary traditions even when the story takes place in a local setting, s/he might refer to foreign literature, or send his or her characters to foreign countries. Thus, the works engage in a process of cultural translation, and a back-and-forth between the familiar and the unfamiliar (Damrosch, 2009a, pp. 86-87).

The features described by Damrosch are very general indeed, and at times even contradictory. He mentions, for example, that works of literature can either place their stories in settings without any reference to real places, or use "glocal" strategies, mixtures of elements both local and global (Damrosch 2009a, pp. 108-109). However, despite my critical remarks, I find his account fruitful as a point of departure for an analysis of The American Girl. It includes several literary features that offer a standpoint from which the negotiations between the local and the global in the novel can be scrutinized. Moreover, Fagerholm actually combines several of the tactics suggested by Damrosch as typical of world literature.

How, then, does the novel reduce the distance between the place of production and the place of reception? Perhaps it was its title that initially aroused interest in the novel from the editors of $O$, The Oprah Magazine? The title, of course, openly informs us of the transnational dimension of the book and brings forward the question of national or geographical belonging and place. The central milieu of The American Girl is called "Trakten" ("the District"), and is located in an area that was previously occupied by "the great land in the east" (Fagerholm, 2010, p. 11). The surroundings consist mostly of marsh, forest, fields and houses with odd names like "the house in the darker part of the woods", the Glass House and the Winter Garden. Fagerholm typically creates new, fictive and utopian spaces for her protagonists to dwell in, and literary scholars Maria Margareta Österholm (2012) and Kaisa Kurikka (2005) have pointed out the heterotopic character of these Fagerholmian spaces and places. Her 
novels often take place in odd, hybrid, and peripheral milieus, in suburbs, amusement parks and summerhouses; that is, in places that exist outside established spaces.

Scholars and reviewers have commented on the similarities between the District and Twin Peaks, the little town familiar from the TV series by the American director David Lynch, shown on television during 1990-1991. ${ }^{9}$ The District and Twin Peaks have several common denominators: the theme (the death of a young woman), the milieu (a small district which is neither urban nor rural), the atmosphere (odd, mystical, non-realistic), and the narrative structure (fragmentary, repetitive). In Fagerholm's District, the features that are reminiscent of the little town in Lynch's series coalesce with the tradition of Finland-Swedish novels, which includes many portrayals of small, claustrophobic places (Mazzarella, 1989), and with a geographical place, that of Porkala, an area in south-western Finland that was occupied by the Soviet Union during 1944-1956. The District consists of heterogeneous elements, both fictive and real, as it simultaneously alludes to the tradition of FinlandSwedish literature, American popular culture, and a place on the map, an important area in the history of Finland. Thus, it renegotiates local and global features in a manner that Damrosch suggests is typical of world literature.

Not only does the milieu described in the novel contain both direct and indirect references to American culture, the story also partly takes place on American soil. The opening pages are almost emblematic in this sense. The American Girl starts with the words: "This is where the music begins" (Fagerholm, 2010, p. 1). In the original text, the deictic character of the sentence is even stronger: "Här börjar musiken" ["Here the music begins"]. The environment depicted is Coney Island, outside New York, and the Swedish word "här" ("here") is repeated several times during the first four pages. The deictic markers locate the reader simultaneously in several places at the same time. On the one hand, the word "here" refers to the immediate textual surroundings of the word; here (and now) on the page; on the 
other, it also opens up a space for the reader's "here and now". However, the place and time depicted is that of "there" and "then": the USA, at the end of the 1960s, a faraway place in the past tense.

The opening pages of the novel also depict objects and thematize developments that can be connected to globalization. A young girl is introduced; she strolls around the amusement park and begs for money. To begin with, she is anonymous; the narrator tells us that she comes from San Francisco, and "before that, from somewhere else" (Fagerholm, 2010 , p. 1). She is characterized by an ongoing mobility; she walks around, she has travelled widely, on her shoulder she carries a bag with the text "Pan Am" on it. ${ }^{10}$ Not only is the bag a powerful symbol of modern jet travel, it is also characteristic of Fagerholm's technique of using objects in her novels to create an impression of a specific historical time and place (Ojajärvi, 2012).

The girl enters a singing booth in order to record a song, then she remembers that she is about to meet someone in a nearby park:

She is going to meet a relative. A distant one. Not the relative, but the distance to the place where the relative lives. It is a place on the other side of the earth.

\#

That was the girl, Eddie de Wire. The American Girl who was found drowned in Bule Marsh, the District, a few years later. A place on the other side of the earth. (Fagerholm, 2010, p. 2) $)^{11}$

The "here" referred to in the fiction, then, constantly moves between immediate proximity and distance, local and global, the USA and Finland. The word is given a transnational meaning and is in a state of movement, and the phrase "on the other side of the earth" 
explicitly and literally articulates the global dimension of Eddie's travels. The some what longer space between the first and the second part in the passage referred to above, contributes to the movement as it is a means to signal of distance in time.

The character of the American girl, as she strolls around Coney Island carrying a Pan Am bag while thinking about places both here and there, both thematizes the history of global mobility and shows the importance of the USA as a culture that Fagerholm uses and transforms into her own terms (see Malmio, 2012). So does the depiction of places in the novel in its mixing of national and international textual and geographical allusions: the figure of Eddie who embodies global travel, and the way in which the narrator situates the reader in a place characterized by a mixture of here and there, national and transnational, Finland and the USA. When The American Girl was presented in O, Oprah Magazine in April 2010, it "returned", allegorically speaking, to the place where it began. Of course the milieu in which the story takes place is fictive and constructed by using images of Coney Island from popular culture, but it is also to a certain degree familiar and "real" to its readers in the USA.

\section{A highly influential celebrity and her book club}

In order to study the reasons for "Fagerholm goes Oprah", some information about Winfrey's media company and its general features is needed. After all, it is here that many of the significant factors in the event can be found. The Oprah Phenomenon, an anthology edited by Jennifer Harris and Elmore Watson (2009), has been a valuable source for me as it gives a profound introduction to Winfrey and her media companies, and also offers feminist perspectives on, and interpretations of, her many actions; among them, the book club.

If Fagerholm is unique, so is Oprah Winfrey, but in a different manner and in another arena. Winfrey is a famous American television hostess who presented a show of her own 
from 1986-2011, and has built a successful media empire. She is also an actress, an activist within the feminist and civil-rights movements, the weight loser of the year and a millionaire, among many other things. She is the most influential African-American woman in the USA, and her life-story is that of the American dream come true. It is about a triumph over hardship and provides her with the authority to talk about self-management, hard work and the development of one's own skills (Harris \& Watson, 2009, pp. 2-3). She is a media personality, who earns millions from her performances, but she has also talked openly about her struggles in life, her abuse and problems, and she strives to unite women from various racial, ethnic, and economic backgrounds. According to Robert Thompson, Winfrey embodies many themes central to contemporary American life, topics like:

[...] race, gender, and consumerism; celebrity, power, and self-righteousness; optimism, jingoism, and altruism. To approach the subject of Oprah Winfrey is to encounter the possibilities and contradictions of life in the Republic. And it's to encounter them on the exaggerated, super-sized scale of the nation itself.

From the standpoint of the 1950s, the idea that an African-American woman would achieve the cultural centrality and power of Oprah Winfrey in just one generation would have seemed highly unlikely. It's a great American story, and like most American stories it's filled with ambiguity and wonder. (Thompson, 2009, p. xvii)

For my analysis, the most important of the topics put forward by Thompson, above, is that of gender. Oprah Winfrey is, as Jennifer Harris and Elwood Watson $(2009$, p. 2) have stated, the master ("or perhaps the mistress", they add) of female networks.

In 1999, Winfrey founded a media company that produced cable and internet programmes for women, and the following year she established $O$, The Oprah Magazine, 
which is published once a month. It is famous for its ability to reach a huge audience and for its large-scale impact on female readers (Hammett and Dentith, 2009, p. 213; Ribbons, 2009, p. 227). O, The Oprah Magazine, has promoted the book club in many ways, as does the overall website of oprah.com where $O$, The Oprah Magazine is also to be found. Oprah's Book Club, launched by Winfrey in 1996 and still running, has been a great success. It has helped many authors to the top of the bestseller lists and has made reading attractive again among people in a time and place where it had almost disappeared (Pereira, 2009, p. 195).

By the time Fagerholm's novel appeared on Oprah Winfrey's website, the book club had already been through several changes and remakes, and its book selections had varied from "popular" to "literary", from US-produced to international, and from classics to contemporary literature (Pereira, 2009, p. 196). However, the book club has been coherent in one particular respect. It has focused throughout on female authors, who write about female characters in novels read predominantly by female readers. In The Oprah Phenomenon, Sarah Ribbons discusses the significance of diversity and race, but finally establishes that "even more important as a key feature shaping the literacy practices of Winfrey's original book club was gender" (Ribbons, 2009, p. 230). The same is stated by Roberta E. Hammett and Audrey Dentith:

Like the audience of The Oprah Winfrey Show and the heroines of the book club selections, the original book club participants were usually women. Female authors outnumbered males by approximately three to one, and almost all the novels' protagonists were female. (Hammett \& Dentith, 2009, p. 213)

The book club has thus become a space for women of all kinds, and a shared experience, particularly for women interested in personal growth. Winfrey has consequently presented herself as a reader in her show and has also, despite her many employees, made all the major decisions concerning the show. On the website of oprah.com, one of the FAQs concerning the 
book club is how an author gets his or her book reviewed in Oprah's Book Club. The answer is, in short, that Oprah Winfrey herself chooses the books that are presented (http://www.oprah.com/oprahsbookclub/Oprahs-Book-Club-FAQ). Malin Pereira sheds some light on this question in her examination of the book selections during the first couple of years of the book club. She states that, although Winfrey might not have single-handedly chosen all the books, it "seems plausible that the selections are made principally by Winfrey and that they reflect, to a large extent, her personal views and reading tastes" (Pereira, 2009, p. 195). The articles in The Oprah Phenomenon demonstrate how Winfrey has consequently privileged reading practices that foreground personal experience and literature as a means of empowerment, self-help and self-improvement.

The uniform message put forward by the various instances connected to Winfrey - her talk show, the book club and the webpages of oprah.com - is important for the book selections, and consequently also for The American Girl. Winfrey is an expert in marketing; her image, her opinions and the products she promotes in her various media all put forward her message through her medium, often even mediated by her self (Harris \& Watson, 2009). She is "Oprah", a phenomenon and a brand, and the commodities she endorses - for example, books - must reflect and contribute to her image. $O$, The Oprah Magazine, which apart from the talk show is the main organ of literacy in Winfrey's media empire, offers ways to spread Winfrey's book club (Harris \& Watson, 2009, p. 25). The club's material, including reading guides, background information and resources, and newsletters sent by email to readers, has been disseminated through electronic media and the pages of oprah.com, including an electronic discussion board where the books are discussed (Hammett \& Dentith, 2009, p. 208). This is the context into which Fagerholm's novel makes it way. 
Den amerikanska flickan was translated by Katarina E. Tucker for Other Press in New York, where it was published in $2010 .{ }^{12}$ The publishing house states that it focuses on "novels, short stories, poetry, and essays from America and around the world that represent literature at its best", and that it "attracts authors who are guided by a passion to discover the limits of knowledge and imagination" (http://www.otherpress.com/about/). Other contemporary Nordic authors whose works have been published by Other Press are the Swedish Ninni Holmqvist, the Danish Peter Høeg and the Norwegian Merete Lindstrøm.

The "quarantine", the time it took before Den amerikanska flickan was translated into English, was 4-5 years, slightly longer than that of Fagerholm's previous book published in the USA, Underbara kvinnor vid vatten (1994), which was translated by Joan Tate for New Press in New York and published as Wonderful Women by the Sea in 1997. Whether the translation of Underbara kvinnor vid vatten had any impact upon the discovery of Den amerikanska flickan is unknown. However, on the back cover of The American Girl, under the headline "Praise for Wonderful Women by the Sea", one finds short citations from the reviews of the novel in the New York Times Book Review and the Boston Globe. The publication date of The American Girl was 16 February 2010, and a review of the novel is found in the April issue of $O$, The Oprah Magazine.

According to Lawrence Venuti, translation is "a fundamentally localizing practice" (Venuti, 2012, p. 180). But so is reception. It is about the interplay between the familiar and the unfamiliar, between the linguistic, literary and historical codes of the text, and the cultural and personal frame of the recipient, between similarity and difference. And the localizing (market) practices can already be seen on the book covers. The European book covers of The American Girl vary greatly, offering different interpretations of the girls Eddie, Sandra and Doris depicted in the novel. All the book covers, however, portray girls, either "real" (photos) or illustrated ones, but always identifiable female figures. [FIGURES 1 (Germany), 2 
(Holland), and 3 (Norway)] The Swedish and Danish book covers are almost identical with the Finland-Swedish original, even using the same photo taken by the Finnish photographer Tuija Lindström. Thus, they signal the cultural similarity between the context of production and that of reception. [FIGURES 4 (Finland-Swedish edition), 5 (Denmark) and 6 (Sweden)]

The front cover by Simon M. Sullivan for the North-American translation makes an interesting exception: it portrays no "real" woman or girl, only the red raincoat that Eddie was wearing when she drowned, an empty "shell". [FIGURE 7 (USA] The cover illustration gives instructions for how a book should be read as it alludes to the narrative style of the novel. The window frame lets us see only a part of the raincoat, thus signalling the framing of the story and a perspective that only covers a part of the object depicted. A strong contrast between light and darkness dominates the picture, creating associations with a theatrical scene, or perhaps that of a cinema. The perspective is odd, partial and vexed, and the illustration emphasizes the many spaces in the novel. It is constructed around an opposition between inside and outside, "natural" and unnatural, clearly visible and diffuse contours. The colours of white and red symbolize the main components of the story: innocence, love and death. In many ways, the book cover signals the novel's literary qualities, as well as its central elements and contradictions. Thus, it might be apprehended as less market oriented than the other covers discussed here, which use recognizable female figures to enhance the interest of a potential buyer/reader.

The review of The American Girl, however, gives the novel a very different kind of framing. Written by editor Karen Holt and published in $O$, The Oprah Magazine in April 2010, it is entitled: “A Helsinki Whodunit: A Masterful, Thoughtful Thriller about a Girl Without a Dragon Tattoo." It is a short text, only half a page. Rather than an analytical evaluation, it is a marketing text and a description of the novel. 
Holt's text includes several details that are strangely at odds with the features of the novel, and are thus important as markers of the receiving context. Despite the fact that the capital of Finland is never mentioned in The American Girl, the novel is described as a detective story that takes place in Helsinki. The real city is of no relevance in the novel, which, on the contrary, as I have shown, creates fictive places characterized by hybridity and transnationalism. Interestingly, the title of the review thus demonstrates the importance of location and geography in the reception of literature, even in this contemporary era in all its arguable globalism. Not only the title but also the first sentence of the review locates the story in Finland, and Fagerholm is described as an "award-winning Scandinavian writer". What is more, even the novel's relation to detective fiction is quite complicated. Even though it begins with the mysterious death of Eddie de Wire, the story is less of a "whodunit" than a profound deconstruction of the generic conventions of a detective story. Fagerholm's novel is a story about three girls, but the reviewer mentions only one female protagonist in her title. What also attracts my attention is the description of The American Girl through a (negative) allusion to Nordic Noir, and to what is probably the best-known example of Scandinavian crime fiction. The title refers to Swedish author Stieg Larsson's Män som hatar kvinnor [Men who hate women] (2005), translated into English as The Girl with the Dragon Tattoo in 2008 [FIGURE 8]. The genuine girl with the dragon tattoo is Lisbeth Salander, the female protagonist of the Millennium trilogy, published in Sweden in 2005-2007. In 2009, according to Ann Steiner, Larsson's three crime novels were the most widely read books in the world apart from four novels in the American Stephanie Meyer's vampire series Twilight (Steiner, 2012, p. 316). Thus, the $O$ review also refers to an important current in the global literary market.

The fact that Fagerholm is reviewed as an unusual representative of Scandinavian crime fiction shows how Oprah Winfrey's book club operates within the trends of the global literary market. The opportunity to relate the novel - if only loosely - to a current in the 
literary field, that of Nordic Noir/Scandinavian crime fiction and to what was at the time its most famous female protagonist, Lisbeth Salander, is taken up. Damrosch exemplifies something similar with the Serbian poet Milorad Pavić, whose first novel Dictionary of the Khazars became a global success thanks to the "confluence of two market forces", the interest in magical realism and peripheral literature that was aroused as a result of the global breakthrough of Salman Rushdie (Damrosch, 2009b, p. 106).

The novel itself is described as "deliciously complex", and Holt's review promises readers identification and thrills: "You'll know just how Doris feels, but unlike her, you'll enjoy the suspense." Holt describes Sandra and Doris as two "lonely local girls" with a tight bond between them, and suggests that Sandra has a secret. The books chosen for Oprah Winfrey's book club often correspond to the following pattern: a female protagonist has an oppressive childhood, and is exposed to abuse and mistreatment, either as a child or an adult. There is also a strong identificatory factor included in reading these stories (Hammett \& Dentith, 2009, p. 214). These traits, the sufferings of a female protagonist, her struggle to build a better future, and the reader's sympathy for and identification with the protagonist, are the features that, according to Hammett and Dentith, unite Winfrey's book-club selections and the nineteenth-century tradition of sentimental novels written for a female audience. But these traits also connect The American Girl to many of the novels selected for Winfrey's book club; Fagerholm's novel meets the requirements of an Oprah book in many respects.

In addition to the review, the book club offers a "Reading group guide" including "Reading questions for The American Girl". This section also emphasizes the element of suspense and thus places the novel in the category of Nordic Noir as the questions are preceded by the following text: "Warning: May contain spoilers." The nine questions focus on the novel's complicated narrative structure, the importance of music within it, Eddie's death and whether Sandra's and Doris's views on her death are correct or not, the tension between 
the local people of the District and the rich summer visitors, the significance of women's liberation in the novel and, finally, the meaning of the many names of the characters. ${ }^{13}$ Here, again, the importance of the localizing of the novel is foregrounded. Any difficulties a reader may have in identifying the actual, geographic location of the story are met in reading question number 8 . It is phrased as follows:

Can you identify "the City by the Sea"? A clue: the novel alludes to an international summit meeting that took place there in the mid-1970s. What do you know about the culture of Finland and the various communities that comprise its population? (http://www.oprah.com/omagazine/The-American-Girl-by-Monika-FagerholmReading-...)

This question triggers the reader to localize the city in terms of history and geography, but it also suggests the educational mission of Winfrey's book club: literature viewed as a source of information about, for example, foreign cultures (Pereira, 2009, p. 203; Ribbons, 2009, p. 247). What is more, it offers still another case of the interplay between "local" and "global" as the summit was a meeting of 35 nations, including the USA, discussing the political situation in Helsinki. What I find surprising, however, is that neither the review nor the reading questions comment upon the ways in which Fagerholm makes use of the USA as a setting in her novel.

Winfrey's background in the civil rights and feminist movements has influenced the goals of her television show as well as her selections for the book club. In both cases, the objectives are to empower women and children and to fight racism (Pereira, 2009, p. 195). Reading question number six focuses on precisely this aspect. It first states that, at the time in which the novel is set, the women's liberation movement was about to begin and that it challenged women to establish their own identities and independence. The reader is then asked to "[n]ame five major female characters and describe how each one displays a separate 
aspect of womanhood". This is in line with the feminist goals of the book club. However, seen from a feminist point of view, Oprah Winfrey and her show host a couple of fundamental contradictions. On the one hand, her show joins the struggle against inequality and for a better life through education; on the other, it promotes individualism, capitalism and consumerism. She has strongly supported the idea of individual freedom controlling social and market forces, which has put her at odds with various feminist critics, particularly feminists of colour, who favour community as a basis of identity (Harris \& Watson, 2009, pp. 26-27).

\section{Conclusions}

A close scrutiny of the characteristics of the books favoured by Oprah Winfrey's Book Club demonstrates that The American Girl shares several features in common with the literature endorsed by the club. Her selections have more often than not included books with a female protagonist and with a plot focused on women-centred issues (Ribbons, 2009, p. 234). As I mentioned at the beginning, Fagerholm is above all the depicter of girls and girlhood, and a creator of fictive rooms of one's own for women. Winfrey's book club is shaped by her feminism and her attempts to instruct her viewers and readers in their struggle towards a better, more emancipated life, and feminist ambitions also guide Fagerholm in her authorship. The themes that unite the "programmes" of Fagerholm and Winfrey, then, are those of female fates and emotions, feminism, and literature as a means of illustrating the possibilities for female protagonists. However, the fates of Fagerholm's protagonists do not coincide with the kind of triumph-over-hardship ending that is typical of Winfrey's book selections. Also, Fagerholm's and Winfrey's feminisms may be very distant from each other. The first is a speaker for a Nordic feminism with its base in the Scandinavian social welfare system and its ideals of equality, the second is not only a feminist, but also a spokeswoman for the American Dream, with its emphasis on individualism, capitalism and consumerism. 
According to Broomans and Jiresch, globalization has led to growing international transmediation and the mixing of cultural and media products, the phases of cultural transfer are in flux and the various centres and peripheries have changed positions (Broomans \& Jiresch, 2011, p. 23). Despite the many changes that result from ongoing globalization, the actors in the field, such as cultural transmitters, can still play an important role (Broomans \& Jiresch, 2011, p.10). When applied to The American Girl, it might be easier than before for a text from a minor literature to enter the global market, but active mediators are still needed in such literary exchanges. More importantly, however, we should notice that we have here a sequence of phases of literary exchange in which the common denominator throughout is female gender: a feminist female author depicting female characters in a novel that was translated by a female translator and published by a female publisher. Afterwards, it is presented by a female reviewer, who writes for a female media figure with an explicit feminist background, in a magazine that has women as its main target group. Thus, the novel both creates and circulates in a "women's room", which might be local or global, but certainly includes female actors at every level of its cultural transfer. The novel moves in a network of female actors, some of whom are feminists, some perhaps not.

What might also have played a role is the fact that, a couple of years before "Fagerholm went Oprah", the book club selections moved towards the kind of literature that Fagerholm writes, as the books selected became more international, and the aim was to let readers visit new places. The global literary current of Nordic Noir certainly paved the novel's way. Here, the forces of gender, feminism, and the global literary market reach a confluence.

The review in $O$, The Oprah Magazine did not make Fagerholm into a celebrity in the USA, nor did the novel's appearance on the pages of oprah.com lead to a great female reading audience or a huge economic success. "Fagerholm goes Oprah" is an event with different significance in its various geo-linguistic contexts. In the "here" of Finland-Swedish literature, 
it is a major event and a dream fulfilled. It is a sign that a work produced within a minor literature can make its way to the centre of the global literary market, and thus enter the domains of world literature and global circulation. For "there", the female community of readers in the USA, created by $O$, The Oprah Magazine, the novel is marketed as an example of Scandinavian crime fiction, depicting two female protagonists with strong emotions and awful fates with which the reader can identify. (The readers of Oprah Winfrey's book club might, however, have felt themselves at least partially cheated if they expected a regular Nordic Noir.) The mixture of the popular and the literary, which is so typical of Fagerholm's novels, might also have contributed - a fact that is highlighted by the review of the novel in O, The Oprah Magazine. Thus, The American Girl unites the two different currents that have dominated the book selections in Oprah Winfrey's book club.

Damrosch takes as his point of departure the idea that any literary work can potentially become world literature and he discusses how texts strive in different ways to reach out to the world, while Broomans and Jiresch focus on the actors, mediators and networks that are responsible for the actual transfer from one culture to another. "Fagerholm goes Oprah" shows that both perspectives are needed in the study of literary exchange. It demonstrates that the reasons for the novel's ability to travel can be found not only in its intrinsic features, but also in the existing female networks. It is equally important to scrutinize the relationship between the characteristics of the work of literature transferred and the actors and networks that facilitate its movement. The transnational features of The American Girl and its many allusions to the recipient culture, but especially the female rooms created in it (and also by it), show the "willingness" of the novel to travel. What is more, they suggest that the novel's own qualities are of importance when the actors and intermediaries - in this case female, and feminist - decide to translate and review this specific Nordic novel on Oprah Winfrey's 
webpages. It is the network of female actors that enabled this historical event in FinlandSwedish minor literature to take place.

\section{References}

Fagerholm, M. (2009). The American girl: A novel. (Katarina E. Tucker, Trans.). New York: Other Press.

Fagerholm, M. (2005/2004). Den amerikanska flickan. Femte tryckningen. Stockholm: Albert Bonniers Förlag.

Fagerholm, M. (1994). Underbara kvinnor vid vatten: En roman om syskon. Femte tryckningen. Stockholm: Albert Bonniers förlag.

Fagerholm, M. (1997). Wonderful women by the sea. (Joan Tate, Trans.). New York: New Press.

Allen, J. K. (2017). Selling Scandinavia at the ends of the earth: Nordic silent film in Australasia. Keynote speech 15.6.2017, Rethinking Scandinavia. CSS Conference 2017, Centre for Scandinavian Studies in Copenhagen - Lund.

Behschnitt, W., \& Nilsson, M. (2013). "Multicultural literatures" in a comparative perspective. In W. Behschnitt, S. De Mul, \& L. Minnaard (Eds.), Literature, language, and 
multiculturalism in Scandinavia and the Low Countries (pp. 1-15). Amsterdam and New York: Rodopi.

Bermann, S. (2012). World literature and comparative literature. In T. D'haen, D. Damrosch, \& D. Kadir (Eds.), The Routledge companion to world literature (pp. 169-179). New York: Routledge.

Broomans, P., \& Jiresch, E. (2011). The invasion of books. In P. Broomans \& E. Jiresch (Eds.), The invasion of books in peripheral literary fields 3: Transmitting preferences and images in media, networks and translation (pp. 9-21). Groningen: Barkhuis.

Castillo, D. A. (2012). Gender and sexuality in world literature. In T. D’haen, D. Damrosch \& D. Kadir (Eds.), The Routledge companion to world literature (pp. 393-403). New York: Routledge.

Damrosch, D. (2009a). Major cultures and minor literatures. In D. Damrosch (Ed.), Teaching world literature (pp. 193-204). New York: Modern Language Association of America.

Damrosch, D. (2009b). How to read world literature. Malden, MA: Wiley-Blackwell.

Damrosch, D. (2009c). Introduction: All the world in the time. In D. Damrosch (Ed.), Teaching world literature (pp. 1-14). New York: Modern Language Association of America. Hammett, R.E., \& Dentith, A. (2009). Some lessons before dying: Gender, morality, and the missing critical discourse of Oprah's book club. In J. Harris \& E. Watson (Eds.), The Oprah phenomenon (pp. 207-226). Updated edition. Lexington, KY: The University Press of Kentucky.

Harris, J., \& Watson, E. (2009). Preface to the updated edition. In J. Harris \& E. Watson (Eds.), The Oprah phenomenon (pp. ix-xi). Updated edition. Lexington, KY: The University Press of Kentucky.

Harris, J., \& Watson, E. (2009). Introduction: Oprah Winfrey as subject and spectacle. In J. Harris \& E. Watson (Eds.), The Oprah phenomenon (pp. 1-31). Updated edition. Lexington, KY: The University Press of Kentucky. 
Helle, A. (2016). When love and death embrace: Monika Fagerholm's The American girl and the glitter scene as postmodern melodrama. In K. Malmio \& M. Österlund (Eds.), Novel districts: Critical readings of Monika Fagerholm (pp. 83-98). Helsinki: Finnish Literature Society.

Holt, K. (2010). A Helsinki whodunit. A masterful, thoughtful thriller about a girl without a dragon tattoo. O, The Oprah Magazine, April 2010 (http://www.oprah.com/omagazine/TheAmerican-Girl-by-Monika-Fagerholm-Book-Rev/ Accessed 6 June 2016).

Ingström, P. (2014). Play and dreadful seriousness in Monika Fagerholm. (http://www.nordicwomensliterature.net/ Accessed 3 May 2017).

Kurikka, K. (2005). Tytöksi-tulemisen tilat. Monika Fagerholmin Diva utopistisena tekstinä. [The spaces of becoming-girl: Monika Fagerholm's Diva as a utopian text] In A. Helle \& K. Kajannes (Eds.), PoMon tila: Kirjoituksia kirjallisuuden postmodernismista. [The space of PoMo. Texts on postmodern literature] (pp. 56-72). Jyväskylä: Kampus Kustannus.

Kurikka, K. (2009). Kirjoittaminen on tarinassa liikkumista. Kulttuurihaitari 4/2009, pp. 3638.

Kurikka, K. (2016). Becoming-girl of writing: Monika Fagerholm's Diva as minor literature. In K. Malmio \& M. Österlund (Eds.), Novel districts: Critical readings of Monika Fagerholm (pp. 38-52). Helsinki: Finnish Literature Society.

Kvist, L. (2005). Smålandsposten, 7 February 2005.

Lehmann, C. (2002). The Oprah wars. American prospect, 2 December 2002, 40.

Malmio, K. (2012). Phoenix-Marvel Girl in the age of fin de siècle: Popular culture as a vehicle to postmodernism in Diva by Finland-Swedish author, Monika Fagerholm. In L. Kirstinä (ed.), Nodes of contemporary Finnish literature (pp. 72-95). Helsinki: Finnish Literature Society. 
Malmio, K., \& Österlund, M. (2016). Introduction. In K. Malmio and M. Österlund (Eds.), Novel districts: Critical readings of Monika Fagerholm (pp. 8-21). Helsinki: Finnish Literature Society.

Mazzarella, M. (1989). Det trånga rummet. En finlandssvensk romantradition. [The narrow room: A Finland-Swedish prose tradition]. Helsingfors: Söderströms.

Ojajärvi, J. (2012). ”Benson \& Hedges-sytyttimellä.” Kulutustavaroiden ja tavaramerkkikerronnan ulottuvuuksia vuosituhannen vaihteen suomalaisessa romaanissa. ["With a Benson \& Hedges lighter." Perspectives on consumerism and consumer goods in turn-of-the-century Finnish novels] Kirjallisuudentutkimuksen aikakausilehti Avain 2/2012, pp. 52-75.

Pereira, M. (2009). Oprah's book club and the American dream. In J. Harris \& E. Watson, The Oprah phenomenon (pp. 191-205). Updated edition. Lexington, KY: The University Press of Kentucky.

Rabe, A. (2013). Svårnystad thrillergåta av Fagerholm. [A baffling thriller enigma by Fagerholm] Svenska Dagbladet 1 February 2013.

Ribbons, S. (2009). Making corrections to Oprah's book club: Reclaiming literary power for gendered literacy management. In J. Harris and E. Watson (Eds.), The Oprah phenomenon (pp. 227-257). Updated edition. Lexington, KY: The University Press of Kentucky.

Steiner, A. (2012). World literature and the book market. In T. D'haen, D. Damrosch, \& D. Kadir (Eds.), The Routledge companion to world literature (pp. 316-324). New York: Routledge. Tidigs, J. (2014). Att skriva sig över språkgränsen: Flerspråkighet i Jac. Ahrenbergs och Elmer Diktonius prosa. [Crossing linguistic borders in writing: Multilingualism in the prose of Jac. Ahrenberg and Elmer Diktonius] Åbo: Åbo Akademi University Press. Diss. 
Thompson, Robert (2009). Foreword. In J. Harris and E. Watson (Eds.), The Oprah

phenomenon (pp. vii-viii). Updated edition. Lexington, KY: The University Press of

Kentucky.

Venuti, L. (2012). World literature and translation studies. In T. D’haen, D. Damrosch, \& D.

Kadir (Eds.), The Routledge companion to world literature (pp. 180-193). New York:

Routledge.

Zilliacus, C. (2000). Finlandssvensk litteratur. [Finland-Swedish literature] In C. Zilliacus

(Publ.), M. Ekman (Ed.), Finlands svenska litteraturhistoria. Andra delen: 1900-talet (pp.

13-18). [Finland-Swedish literature history. Part two: the twentieth century] Helsingfors,

Stockholm: Svenska litteratursällskapet i Finland, Bokförlaget Atlantis.

Österholm, M. M. (2012). Ett flicklaboratorium i valda bitar: Skeva flickor i svenskspråkig

prosa från 1980 till 2005. [A girl laboratory in chosen parts: Queer girls in Swedish and

Finland-Swedish literature from 1980 to 2005] Stockholm: Rosenlarv förlag.

\footnotetext{
${ }^{1}$ Broomans and Jiresch (2011, p. 10) use a model based on Johan Heilbron \& Gisèle Sapiro (2007), which they then extend by involving gender and ideology.

${ }^{2}$ O, The Oprah Magazine as well as Oprah's Book Club can be found on the website oprah.com.

${ }^{3}$ Despite considerable efforts, I have not been able to contact the translator of The American Girl, Katarina E. Tucker, or the publishing house in New York, Other Press. Thus, I have not been able to gather information about how the translator was introduced to the book and why she decided to translate it, nor do I have any detailed evidence about the role of the publishing house in the process. Fagerholm's literary agent in Sweden, Salomonsson Agency, has not answered my enquiries, and I have not been able to identify material about how the translation found its way to Oprah's Book Club. In a discussion I had with Monika Fagerholm in August 2016, she mentioned that Judith Gurewich, the founder of Other Press, was active in the process of translation, but Fagerholm did not remember any details.

${ }^{4}$ There is also a British translation of the novel from the same year and by same translator, Joan Tate, for Harvill Press in London, entitled: Wonderful women by the water.

${ }^{5}$ The most successful authors of Finland-Swedish literature often have a publishing house in both Finland and Sweden. This is also the case with Fagerholm, and the Swedish edition of her books is usually published a couple of months later than the Finland-Swedish edition.

${ }^{6}$ This is the sense in which Deleuze and Guattari use the term, as Damrosch (2009b, p. 194) points out.

${ }^{7}$ David Damrosch is more optimistic on this point. He argues that "dramatic imbalances persist today in translation between more and less powerful countries, but literature now circulates in multiple directions and writers in even very small countries can aspire to reach a global readership" (Damrosch, 2009b, p. 106).

${ }^{8}$ Damrosch notes that "definitions of world literature have oscillated among three basic paradigms; as classics, as masterpieces, and as windows to the world" (2009c, p. 3).

${ }^{9}$ In an interview, Fagerholm has described Lynch's series as the "ultimate way to depict a small town" (Rabe, 2013).
} 
10 "Pan Am", short for Pan American World Airlines, was an American airline company, established in 1927 and one of the first to operate international flights between continents.

11 "Hon ska träffa en släkting. En avlägsen en. Inte släktingen i sig, men avståndet till den plats där släktingen bor. Det är en plats på andra sidan jordens klot. / Det var flickan, Eddie de Wire. Den amerikanska flickan som några år senare hittades drunknad i Bule träsket, Trakten, en plats på andra sidan jordens klot” (Fagerholm, 2005 , p. 8). The emphasis in the original on the words "on the other side of the earth" has been left out in the translation.

${ }^{12}$ According to the translation database of FILI (Finnish Literature Exchange), the centre for the export of Finnish literature, Den amerikanska flickan has been translated into ten languages: Finnish (2004), Dutch (2005), French (2007), Norwegian (2007), German (2008), Serbian (2008), English (2009), Hungarian (2010), Russian (2011), and Albanian (2012). Salomonsson Agency, which represents Fagerholm, has sold the rights to the book to 12 publishing houses in several different countries, including Albert Bonniers förlag in Sweden. The Danish translation of the novel (2007) is missing from FILI's database.

${ }^{13}$ The questions that are posed about The American Girl are, then, similar to those put forward in the earlier phases of the book club, and in the discussions that took place on the show. According to Hammett \& Dentith (2009, p. 210), "Discussions tended to center around what given scenes or events signified, what metaphors and symbols were used by the author and what they denoted, what the various characters in the work represented, and what the themes were and how various textual elements contributed to their development." And: [...] "This emphasis on themes, plotline and structure, narrative style of the author (including voice), characters and their actions, and the meaning or significance of quotations, objects, or events was also evident in the other book club forums. Questions about these aspects of the books were common in the electronic discussion boards, and during the book club shows, Winfrey often focused the conversation on these elements" Hammett \& Dentith (2009, p. 211). 